\title{
Anodic Benzylic C(sp3)-H Amination: A Unified Access to Pyrrolidines and Piperidines
}

\author{
Sebastian Herold, ${ }^{a}$ Daniel Bafaluy, ${ }^{a}$ Kilian Muñiz*a,b \\ www.rsc.org/
}

\begin{abstract}
An electrochemical aliphatic $\mathrm{C}-\mathrm{H}$ amination strategy was developed to access the important heterocyclic motifs of pyrrolidines and piperidines within a uniform reaction protocol. The mechanism of this unprecedented $\mathrm{C}-\mathrm{H}$ amination strategy involves an anodic $\mathrm{C}-\mathrm{H}$ activation to generate a benzylic cation, which is efficiently trapped by the nitrogen nucleophile. The applicability of the process is demonstrated for 40 examples comprising both 5- and 6membered ring formation.
\end{abstract}

Pyrrolidines and piperidines are among the most significant saturated nitrogen heterocycles in Nature, being present in numerous natural products. ${ }^{1}$ They also exhibit essential pharmacophoric properties and thus constitute prominent molecular components in pharmaceutical structure development. ${ }^{2}$ Their nature as saturated aminated heterocycles renders them ideal representatives of the "escape from flatland" concept. ${ }^{3}$ The quest for new accesses towards this class of compounds has been a constant source for synthetic innovation. Recently, the direct functionalization of aliphatic C$\mathrm{H}$ bonds has been identified as a logical strategy for the formation of such higher-functionalized molecules. ${ }^{4}$ Within this context, molecular catalysts have demonstrated conceptual utility for certain intramolecular $\mathrm{C}-\mathrm{H}$ amination reactions, which have been developed to an impressive extent based on transition metal catalysis. ${ }^{5}$ Therein, the formation of new alkylnitrogen bonds is predominantly based on nucleophilic nitrogen groups $^{6}$ and metal nitrene insertions ${ }^{7}$ into aliphatic hydrocarbon bonds. Despite high levels of efficiency, such metal-catalysed reactions commonly rely on non-carbon spacer units activating and/or stabilizing the nitrogen atom involved in the $\mathrm{C}-\mathrm{H}$ amination reaction. This generates heterocycles that differ from naturally occurring cycloamines. Recent advances in the area have overcome this limitation. ${ }^{8}$ Still, extended use of precious metal promoters are considered problematic due to removability of trace metal impurities or economic reasons. Aliphatic $\mathrm{C}-\mathrm{H}$ bond amination can also be achieved by catalytic versions ${ }^{9}$ of classic amidyl radical chemistry. ${ }^{10}$ Despite the impressive advance, no general environmentally benign synthesis concept is currently available that would reach out for both five- and six-membered ring formation in intramolecular $\mathrm{C}-\mathrm{H}$ amination. ${ }^{11}$

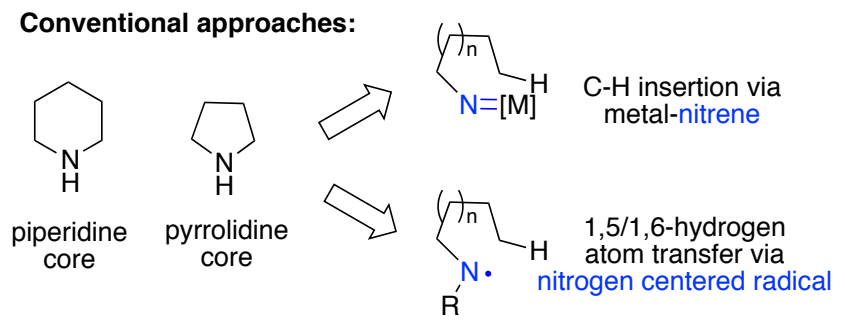

This work: uniform electrochemical $\mathbf{C}-\mathrm{H}$ amination
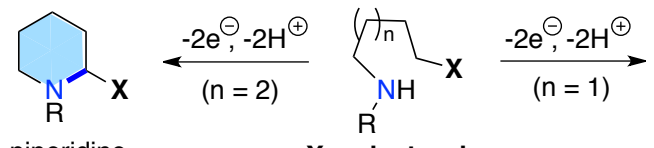<smiles>[X]C1CCCN1</smiles>

piperidine $\mathrm{X}=$ electrophore

pyrrolidine

Scheme 1 Aliphatic C-H amination

We have now envisioned an electrochemical strategy to selectively and sustainably access pyrrolidines and piperidines within a unified protocol. This approach employs a suitably positioned electrophoric group to direct $\mathrm{C}-\mathrm{H}$ amination within electrochemical oxidation. Synthetic organic electrochemistry has recently attracted a lot of attention and is recognized as an environmentally benign methodology in the tool kit of the organic chemist. ${ }^{12,13}$ While the formation of pyrrolidines and piperidines by intramolecular electrochemical amination of electron-rich alkenes is well known and has been extensively studied, ${ }^{14}$ until now the corresponding anodic amination of unfunctionalised aliphatic $\mathrm{C}-\mathrm{H}$ bonds remains a notably underdeveloped field..$^{15}$

Initial experiments were carried out using similar conditions reported in literature for the electrochemical generation of nitrogen centred radicals. ${ }^{14 a-c}$ We rationalized that the anodic formation of amidyl radicals should lead to a 1,5- $\mathrm{H}$ transfer ${ }^{8 \mathrm{a}, \mathrm{f}}$ and subsequently to the desired pyrrolidines. Starting from model compound 1a, optimization studies were performed in an undivided cell, using a graphite rod anode and a platinum cathode. ${ }^{16} \mathrm{~A}$ constant current of $5 \mathrm{~mA}$ and a charge of $2.2 \mathrm{~F}$ were applied. Using methanol or mixtures of methanol and THF with 
$\mathrm{LiClO}_{4}$ as supporting electrolyte and sodium methoxide as base the desired pyrrolidine $2 \mathrm{a}$ was only obtained in yields of up to 25\% (Table 1, entries 1 and 2). Changing the supporting electrolyte to $\mathrm{Et}_{4} \mathrm{NOTs}$ and $\mathrm{Bu}_{4} \mathrm{NPF}_{6}$ did not improve the yield (Table 1, entries 3 and 4). We then altered the solvent to 1,1,1,3,3,3-hexafluoroisopropanol (HFIP). HFIP has proven beneficial in electroorganic transformations due to its ability to stabilize and enhance the lifetime of anodically generated reactive intermediates such as radical cations. ${ }^{17,} 18$ To reduce the fluorine footprint, HFIP can be redistilled.

Table 1 Optimization of electrolysis conditions.

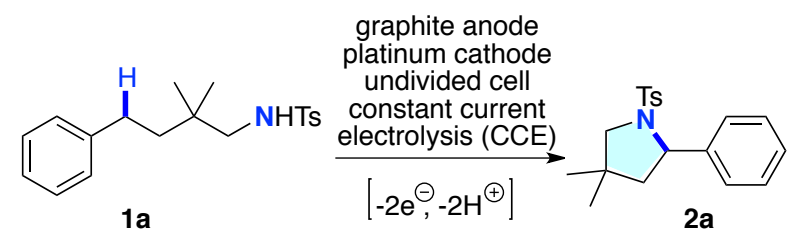

\begin{tabular}{|c|c|c|c|c|}
\hline \multirow[b]{2}{*}{ Entry } & \multirow[b]{2}{*}{ Electrolyte } & \multirow[b]{2}{*}{ Additive } & \multicolumn{2}{|c|}{ Yield [\%] } \\
\hline & & & $1 a$ & $2 a$ \\
\hline 1 & $0.1 \mathrm{M} \mathrm{LiClO}_{4} / \mathrm{MeOH}$ & $\begin{array}{l}0.5 \text { eq. } \\
\text { NaOMe }\end{array}$ & 56 & 23 \\
\hline 2 & $\begin{array}{l}0.1 \mathrm{M} \mathrm{LiClO}_{4}, 60 \% \\
\mathrm{MeOH} / \mathrm{THF}\end{array}$ & $\begin{array}{l}0.5 \text { eq. } \\
\text { NaOMe }\end{array}$ & 57 & 25 \\
\hline 3 & $0.1 \mathrm{M} \mathrm{Et}_{4} \mathrm{NOTs} / \mathrm{MeOH}$ & $\begin{array}{l}0.5 \text { eq. } \\
\text { NaOMe }\end{array}$ & 87 & trace \\
\hline 4 & $0.1 \mathrm{M} \mathrm{Bu}_{4} \mathrm{NPF}_{6} / \mathrm{MeOH}$ & $\begin{array}{l}0.5 \text { eq. } \\
\text { NaOMe }\end{array}$ & 92 & trace \\
\hline 5 & $0.1 \mathrm{M} \mathrm{Bu}_{4} \mathrm{NPF}_{6} / \mathrm{HFIP}$ & - & n.d. & 67 \\
\hline $6^{[a]}$ & $0.1 \mathrm{M} \mathrm{Bu}_{4} \mathrm{NPF}_{6} / \mathrm{HFIP}$ & - & n.d. & 61 \\
\hline $7^{[b]}$ & $0.1 \mathrm{M} \mathrm{Bu}_{4} \mathrm{NPF}_{6} / \mathrm{HFIP}$ & - & n.d. & 52 \\
\hline $8^{[c]}$ & $0.1 \mathrm{M} \mathrm{Bu}_{4} \mathrm{NPF}_{6} / \mathrm{HFIP}$ & - & n.d. & 77 \\
\hline $9^{[d]}$ & $0.1 \mathrm{M} \mathrm{Bu}_{4} \mathrm{NPF}_{6} / \mathrm{HFIP}$ & - & trace & 70 \\
\hline $10^{[c]}$ & $\begin{array}{l}0.1 \mathrm{M} \mathrm{Bu}_{4} \mathrm{NPF}_{6}, 50 \% \\
\mathrm{CH}_{3} \mathrm{CN} / \mathrm{HFIP}\end{array}$ & - & trace & 24 \\
\hline $11^{[c]}$ & $0.05 \mathrm{M} \mathrm{Bu}_{4} \mathrm{NPF}_{6} / \mathrm{HFIP}$ & - & n.d. & 65 \\
\hline $12^{[\mathrm{c}]}$ & $0.1 \mathrm{M} \mathrm{Et}_{4} \mathrm{NOTs} / \mathrm{HFIP}$ & - & - & 53 \\
\hline $13^{[c]}$ & $0.1 \mathrm{M} \mathrm{Bu}_{4} \mathrm{NBF}_{4} / \mathrm{HFIP}$ & - & n.d. & 85 \\
\hline $14[c]$ & $0.05 \mathrm{M} \mathrm{Bu}_{4} \mathrm{NBF}_{4} / \mathrm{HFIP}$ & - & n.d. & 68 \\
\hline $15^{[c]}$ & $0.2 \mathrm{M} \mathrm{Bu}_{4} \mathrm{NBF}_{4} / \mathrm{HFIP}$ & - & n.d. & 70 \\
\hline $16^{[c, e]}$ & $0.1 \mathrm{M} \mathrm{Bu}_{4} \mathrm{NBF}_{4} / \mathrm{HFIP}$ & - & n.d. & 80 \\
\hline $17^{[\mathrm{f}]}$ & $0.1 \mathrm{M} \mathrm{Bu}_{4} \mathrm{NBF}_{4} / \mathrm{HFIP}$ & - & n.d. & 73 \\
\hline
\end{tabular}

Isolated yields. $0.2 \mathrm{mmol}$ substrate; I = $5 \mathrm{~mA}, 2.2 \mathrm{~F}$; [a] $2.0 \mathrm{~F}$; [b] $2.4 \mathrm{~F}$; [c] I = 2.5 $\mathrm{mA} ;[\mathrm{d}] \mathrm{I}=1.5 \mathrm{~mA}$; [e] $1.0 \mathrm{mmol}$ substrate scope; [f] $3.0 \mathrm{mmol}$ substrate scope; n.d. $=$ not determined.

The use of HFIP as solvent led to dramatically improved yields of up to $67 \%$ of $\mathbf{2 a}$ (Table 1 , entry 5). Having identified HFIP as optimum solvent for this electrochemical transformation, the amount of charge was varied in the range of 2-2.4 $\mathrm{F}$ (Table 1, entries 6 and 7) as well as the applied current (1.5-5 mA, Table 1, entries 5, 9 and 13). Furthermore, the effect of the concentration of the supporting electrolyte was investigated (Table 1, entries 14 and 15 ). The best yield (Table 1 , entry 13 ) of the corresponding pyrrolidine $2 a$ was obtained by using a $0.1 \mathrm{M} \mathrm{Bu}_{4} \mathrm{NBF}_{4} / \mathrm{HFIP}$ electrolyte, a current of $2.5 \mathrm{~mA}$ and $2.2 \mathrm{~F}$. To test the robustness of the reaction, experiments at 1 and $3 \mathrm{mmol}$ scale of substrate $1 \mathrm{a}(0.33 \mathrm{~g}$ and $1 \mathrm{~g}$, respectively) were conducted without any change in reaction conditions leading to $73-80 \%$ of isolated 2 a (Table 1 , entries 16 and 17). This demonstrates that the cyclization proceeds equally efficient at higher substrate concentration.

With the optimized electrolysis conditions in hand, we explored the scope of the reaction (Figure 1). Different sulphonyl protecting groups on the nitrogen are tolerated including 4-nosyl, mesyl and SES (2a-d). The possible use of SES and $\mathrm{Ns}$ is important in order to access the corresponding free

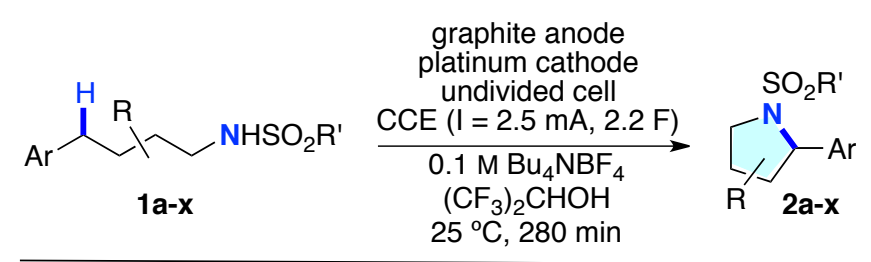

2a $(R=T s): 85 \%$

$2 b$ ( $R=4-\mathrm{Ns}): 51 \%$

2c $(R=M s): 73 \%$

2d $(\mathrm{R}=\mathrm{SES}): 37 \%$
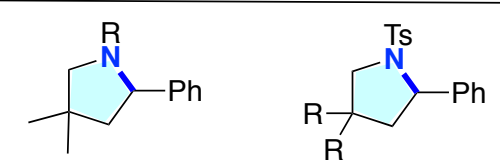

2e $\left[\mathrm{R}_{2}=\left(\mathrm{CH}_{2}\right)_{5}\right]: 89 \%$

$2 f(R=H): 55 \%$

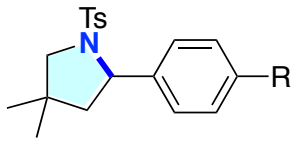

2i $\left(\mathrm{R}=\mathrm{CH}_{3}\right): 84 \%$ 2j $(R=F): 83 \%$

2k $(\mathrm{R}=\mathrm{Cl}): 52 \%$<smiles>[R]c1ccc(C2c3ccccc3CN2S)cc1</smiles>

$2 \mathrm{~m}\left(\mathrm{R}=\mathrm{CH}_{3}\right): 77 \%$ 2n $(\mathrm{R}=\mathrm{Cl}): 83 \%$ 20 $(R=F): 56 \%$ $2 p\left(R=\mathrm{CF}_{3}\right): 56 \%$ $2 q\left(R={ }^{t} B u\right): 62 \%$<smiles></smiles>
2r: $48 \%$ a<smiles>O=S1(=O)c2ccccc2C2CCCN21</smiles><smiles>[NH3+]C1CCC2Cc3ccccc3C12</smiles><smiles>[3H]N1C(c2ccccc2)CC[C@H]1C</smiles>

$R^{\prime \prime}$

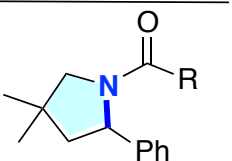

$2 g(R=P h): 65 \%$ 2h $\left(\mathrm{R}=\mathrm{CF}_{3}\right): 60 \%$

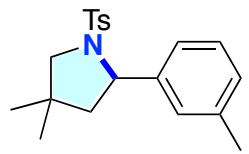

2I: $63 \%$

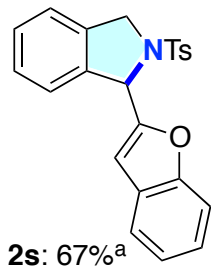<smiles>CPC1CC(P)[N]C1P</smiles>

2t: $30 \%$

2u: $87 \%$

2v: $46 \%, 1.2: 1 \mathrm{dr}$ 2x $\left(\mathrm{R}=\mathrm{C}_{2} \mathrm{H}_{5}\right)$ $64 \%, 2: 1 \mathrm{dr}$ $67 \%, 2.5: 1 \mathrm{dr}$

pyrrolidines under mild conditions.

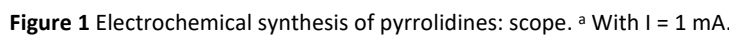


Furthermore, it is possible to perform the transformation with modified backbone (2e) and without any substitution in the alkyl backbone (2f), demonstrating that a Thorpe-Ingold effect is not required, although in this case the isolated yield is slightly lower (55\%) compared to the similar substrates $2 \mathrm{a}$ and 2e. Not only sulphonyl but also carbonyl substituents at the nitrogen functionality can be employed to yield the corresponding amides in good yields $(\mathbf{2 g}, \mathbf{h})$. Typical organic substituents including methyl, chloro and fluoro groups are well tolerated on the arene as demonstrated for derivatives $\mathbf{2} \mathbf{i}-\mathbf{k}$. The $\mathrm{C}-\mathrm{H}$ amination scope also includes substrates with a phenyl backbone. The corresponding isoindolines $\mathbf{2 m - 2 q}$ are formed in very good yields tolerating chloro, fluoro, alkyl as well as trifluoromethyl substitution in the 4-position of the aryl moiety. For the case of heteroarene substitution, $\mathbf{2} r$ and $\mathbf{2 s}$ are formed in considerable yields tolerating the electron-rich thiophene and benzofurane cores, respectively. In addition, transannular cyclisations are possible as demonstrated for $\mathbf{2 t}$. Diastereomerically pure pyrrolidine $\mathbf{2} \mathbf{u}$ was obtained as a result of cyclic stereocontrol. In the case of substrates bearing monosubstitution in the alkyl chain, acyclic stereocontrol with a diastereomeric excess of up to $2.5: 1$ for the trans:cis-ratio was observed (2v-2x). These latter experiments provided a first indication that the cyclization most likely occurs through a planarised benzylic cation allowing for minor diastereoselection. Besides the main interest in amination reactions, the possibility to include oxygen nucleophiles to trap the anodically generated benzylic cation was briefly explored (Scheme 2). Under standard conditions, cyclization of 4-phenyl butanol 3a was straightforward to provide 2-phenyl tetrahydrofurane $\mathbf{4 a}$. In the same manner, 4-phenyl butanoic acid $\mathbf{3 b}$ generated the 5-membered lactone $\mathbf{4 b}$ in high yield. ${ }^{19}$

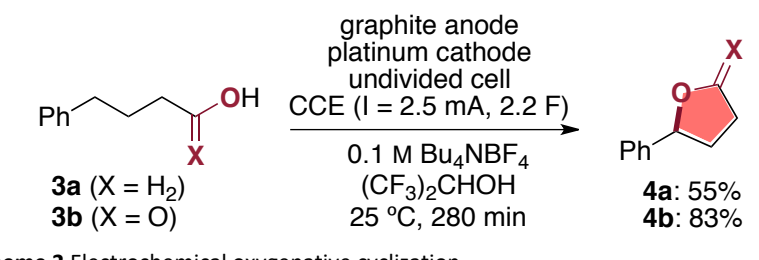

Scheme 2 Electrochemical oxygenative cyclization.

The scope of the $\mathrm{C}-\mathrm{H}$ amination reaction could be directly expanded to the formation of piperidines 6a-q. Figure 2 displays several examples of such a 6-membered ring formation under the mild and operational simple electrochemical conditions. The cyclization proceeds well for tosylamides $\mathbf{5 a , b}$ with different backbone substitution and for $\mathbf{5 c}$ with a functionalized benzenesulfonamide. As expected, common functional groups are well tolerated as substituents at the 4- and the 3-position of the arene group demonstrating the broad scope of the transformation (6d-6j). A substrate with a phenyl backbone efficiently yielded the corresponding tetrahydroisoquinoline $\mathbf{6 k}$ in excellent yield of $81 \%$. The reaction could also be applied to generate the new benzo-fused bicycle 61 . The stereochemistry of the piperidine formation is comparable to the observations from pyrrolidine formation. Amination under cyclic stereocontrol proceeds with $100 \%$ selectivity as determined for $6 \mathrm{~m}$ and $6 \mathrm{n}$, while acyclic stereocontrol provides a slight preference for the trans-diastereoisomer $(\mathbf{6 0}, \mathbf{p})$. Although in lower yield, the amination conditions could also be extended to the synthesis of piperazine $\mathbf{6 q}$.

Figure 2 Electrochemical synthesis of piperidines: scope.

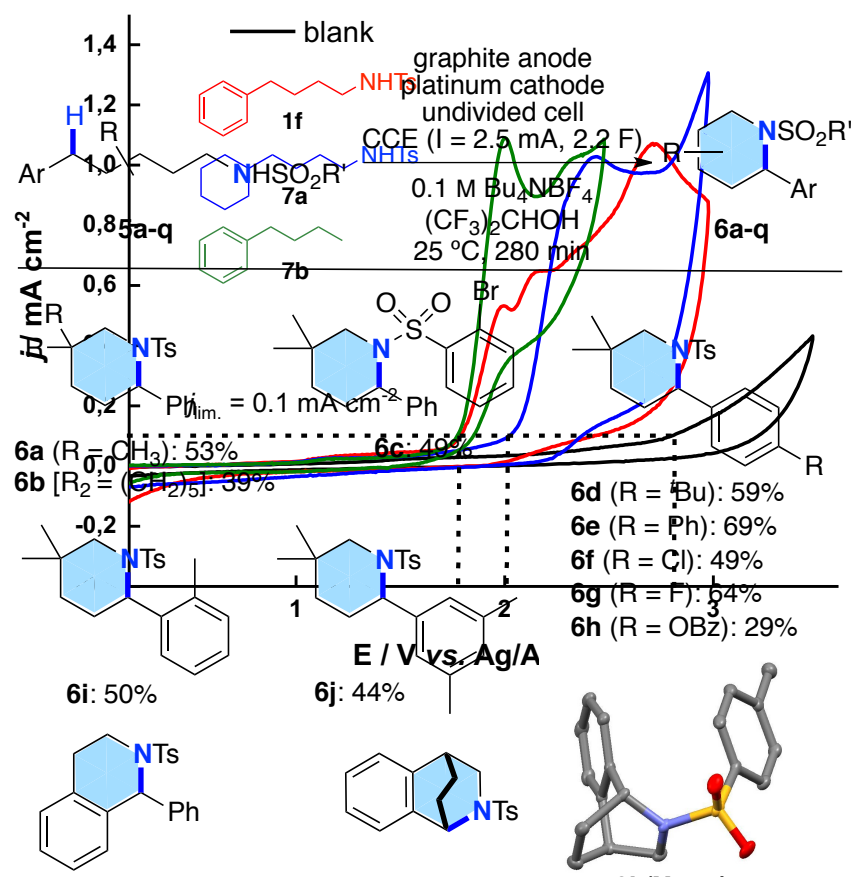

6k: $81 \%$

6I: $40 \%$

6I (X-ray)

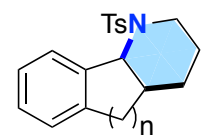

$\mathrm{R}$,

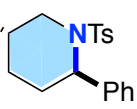

$\overbrace{P h}^{N N s}$

$6 m(n=1): 54 \%$

$6 n(n=2): 48 \%$

$60\left(\mathrm{R}=\mathrm{CH}_{3}\right): 59 \%, 1.7: 1 \mathrm{dr}$

$6 p\left(R=\mathrm{C}_{2} \mathrm{H}_{5}\right): 49 \%, 1.5: 1 \mathrm{dr}$

$6 q: 24 \%$

Figure 3 Cyclic voltammetry of $\mathbf{1 f}$ ( $3 \mathrm{mM}$, red line), $7 \mathbf{a}$ ( $3 \mathrm{mM}$, blue line) and $\mathbf{7 b}$ ( $3 \mathrm{mM}$ green line). The voltammogram for the blank electrolyte is shown for comparison (black line). Working electrode: glassy carbon; counter electrode: platinum wire; reference electrode: $\mathrm{Ag} / 0.01 \mathrm{M} \mathrm{AgNO}_{3}$ in $0.1 \mathrm{M} \mathrm{Bu}_{4} \mathrm{NClO}_{4}$; scan rate: $50 \mathrm{mV} \mathrm{s}^{-1}$.

In order to study the mechanistic aspects of the process, we performed cyclic voltammetric studies of model compounds $\mathbf{1 f}$ (Figure 3, red line), 7a (Figure 3, blue line) and 7b (Figure 3, green line) in $0.1 \mathrm{M} \mathrm{Bu}_{4} \mathrm{NBF}_{4} / \mathrm{HFIP}$. Each solution contained a concentration of $3 \mathrm{mM}$ of the corresponding substrate. By comparing the oxidation potentials of the three model substrates $\mathbf{1 f}, \mathbf{7 a}$ and $\mathbf{7 b}$ it should be possible to determine whether the amine functionality or the aromatic core is oxidized first. Initially, the $\mathrm{CV}$ of the blank electrolyte $0.1 \mathrm{M}$ $\mathrm{Bu}_{4} \mathrm{NBF}_{4} / \mathrm{HFIP}$ (black line) was measured demonstrating the outstanding stability of HFIP based electrolytes towards anodic oxidation. ${ }^{20}$ Significant degradation of the electrolyte only starts at $2.80 \mathrm{~V}$ vs. $\mathrm{Ag} / \mathrm{AgNO}_{3}$ with a cut-off current density for oxidation defined as $j_{\mathrm{lim}}=0.1 \mathrm{~mA} \mathrm{~cm}^{-2}$. Compound $\mathbf{1 f}$ bearing both the aromatic core and the amino functionality is irreversibly oxidized at a potential of $1.79 \mathrm{~V}$ vs. $\mathrm{Ag} / \mathrm{AgNO}$. The oxidation for tosylamide 7a without the aromatic core is $230 \mathrm{mV}$ higher at $2.02 \mathrm{~V}$ vs. $\mathrm{Ag} / \mathrm{AgNO}_{3}$ whereas the oxidation of model compound $\mathbf{7 b}$ takes place at $1.77 \mathrm{~V}$ vs. $\mathrm{Ag} / \mathrm{AgNO}_{3}$. Furthermore, the $\mathrm{CV}$ of pyrrolidine product $\mathbf{2} \mathrm{f}$ was measured, ${ }^{16}$ which reveals that oxidation of $2 \mathrm{f}$ takes place at $1.88 \mathrm{~V}$ vs. $\mathrm{Ag} / \mathrm{AgNO} \mathrm{N}_{3}$. This is $90 \mathrm{mV}$ above the oxidation of substrate $\mathbf{1} f$ thus ensuring clean 
product formation. Although not investigated at present, redox mediators may allow for additional selectivity increase for electron-rich substrates. ${ }^{12 \mathrm{~h}}$ The results depicted in Figure 3 allow for a conclusion regarding the mechanism of the electrochemical intramolecular $\mathrm{C}-\mathrm{H}$ amination (Figure 4).
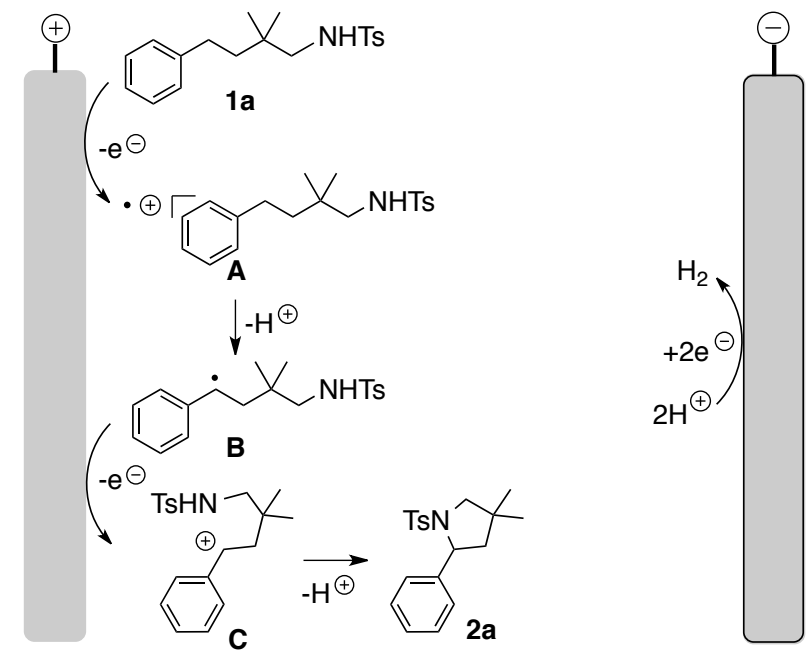

Figure 4 Proposed mechanism with 1a as representative substrate.

Interpreting the data from cyclic voltammetry, the aromatic core was identified as the functional group, which is engaging in the initial oxidation. This is evidenced by the comparable oxidation potentials of phenyl-containing compounds $\mathbf{1} \mathbf{f}$ and $\mathbf{7 b}$, while oxidation of the aliphatic tosylamide $7 a$ occurs at significantly higher potentials. ${ }^{21}$ This concludes that from the involved aryl and tosylamide functional groups the former one acts as electrophore at the outset of the reaction. Upon single electron transfer (SET), an aromatic radical cation $\mathbf{A}$ is thus formed. Because of the positive charge, the acidity of the benzylic hydrogens is dramatically increased by several magnitudes of order. ${ }^{22}$ Thus, deprotonation occurs readily leading to benzylic radical $\mathbf{B}$. Such benzylic radicals are as a rule oxidized at lower potentials than the corresponding neutral substrate 1a. ${ }^{23}$ Further SET generates a benzylic cation $\mathbf{C}$, which is efficiently trapped by the nucleophilic tosylamide. The formation and trapping of a benzylic cation is further supported by our observation of diastereomeric excesses in the cases of acyclic stereocontrol with compounds $\mathbf{1} \mathbf{u}-\mathbf{w}, \mathbf{5 0 , p}$. In contrast, $\mathrm{C}-\mathrm{N}$ bond formation involving radical pathways provides equal mixtures of diastereomers. ${ }^{9}$

Finally, electrochemical oxidation of alcohol 8 leads to C-C cleavage and provides the 2-alkoxylated pyrrolidine 9.16 The same compound can be accessed through a Shono oxidation ${ }^{24}$ of $\mathrm{N}$-tosyl pyrrolidine in the presence of HFIP (52\% yield). Compound $\mathbf{9}$ serves as a versatile synthon for Grignard addition to provide access to pyrrolidines with elusive 2-substitution outside the aryl motif (Scheme 3). ${ }^{25}$

Scheme 3 Electrochemical access to 2-substituted pyrrolidines.

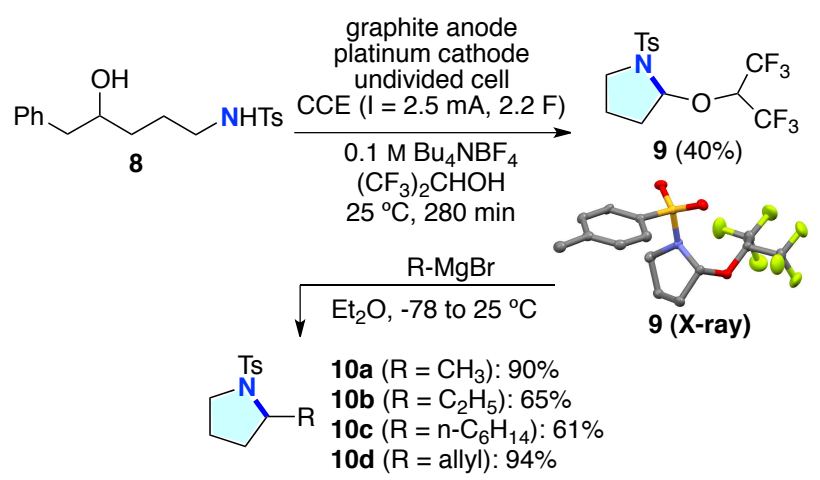

\section{Conclusions}

To conclude, we have developed a mild and atomeconomical intramolecular $\mathrm{C}\left(\mathrm{sp}^{3}\right)-\mathrm{H}$ amination to access pyrrolidine and piperidine scaffolds under uniform reaction conditions. This unprecedented $\mathrm{C}-\mathrm{N}$ bond formation has been enabled by use of an anodic $\mathrm{C}\left(\mathrm{sp}^{3}\right)-\mathrm{H}$ bond activation. The resulting straightforward heterocycle synthesis provides an attractive green alternative to existing protocols and is compatible with a diverse range of functional groups.

\section{Conflicts of interest}

There are no conflicts to declare.

\section{Acknowledgements}

We thank the Spanish Ministry for Economy and Competitiveness and FEDER (CTQ2017-88496R grant to K. M., Severo Ochoa Excellence Accreditation 2014-2018 to ICIQ, SEV-2013-0319) for financial support. The authors are grateful to the CERCA Programme of the Government of Catalonia and to COST Action CA15106 "C-H Activation in Organic Synthesis" (CHAOS).

\section{Notes and references}

1 (a) E. Fattorusso and O. Taglialatela-Scafati, Modern Alkaloids, (Eds.: E. Fattorusso, O. Taglialatela-Scafati) Wiley-VCH, Weinheim, 2007. (b) D. O'Hagan, Nat. Prod. Rep., 2000, 17, 435.

2 E. Vitaku, D. T. Smith and J. T. Njardarson, J. Med. Chem., 2014, 57, 10257.

3 (a) F. Lovering, J. Bikkert and C. Humblet, J. Med. Chem., 2009, 52, 6752. (b) F. Lovering, Med. Chem. Commun., 2013, 4, 515.

4 (a) T. Brückl, R. D. Baxter, Y. Ishihara and P. S. Baran, Acc. Chem. Res., 2012, 45, 826. (b) B. G. Hashiguchi, S. M. Bischof, M. M. Konnick and R. A. Periana, Acc. Chem. Res., 2012, 45, 885. (c) T. W. Lyons and M. S. Sanford, Chem. Rev., 2010, 110, 1147. (d) J. L. Jeffrey and R. Sarpong, Chem. Sci., 2013, 4, 4092.

5 (a) H. M. L. Davies and M. S. Long, Angew. Chem. Int. Ed., 2005, 44, 3518. (b) R. Hili and A. K. Yudin, Nature Chem. Biol., 2006, $2,284$.

6 (a) T. A. Ramirez, B. Zhao and Y. Shi, Chem. Soc. Rev., 2012, 41 , 931. (b) A. McNally, B. Haffemayer, B. S. L. Collins and M. J. Gaunt, Nature, 2014, 510, 129.

7 (a) J. L. Roizen, M. E. Harvey and J. DuBois, Acc. Chem. Res. 2012, 45, 911. (b) F. Collet, C. Lescot and P. Dauban, Chem. 
Soc. Rev., 2011, 40, 1926. (c) P. Dauban and R. H. Dodd, Synlett, 2003, 11, 1571. (d) M. M. Díaz-Requejo, A. Caballero, M. R. Fructos and P. J. Pérez, Catalysis by Metal Complexes Vol. 38 (Ed. P. J. Pérez), Springer, Berlin, 2012, Chapter 6, Pp. 229-264.

8 (a) J. C. K. Chu and T. Rovis, Angew. Chem. Int. Ed., 2018, 57, 62. (b) I. T. Alt, C. Guttrof and B. Plietker, Angew. Chem. Int. Ed., 2017, 56, 10582. (c) D. A. Iovan and T. A. Betley, J. Am. Chem. Soc., 2016, 138, 1983. (d) D. A. lovan, M. J. T. Wilding, Y. Baek, E. T. Hennessy and T. A. Betley, Angew. Chem. Int. Ed., 2017, 56, 15599. (e) O. Villanueva, N. M. Weldy, S. B. Blakey and C. E. MacBeth, Chem. Sci., 2015, 6, 6672. (f) L. M. Stateman, K. M. Nakafuku and D. A. Nagib, Synthesis, 2018, $50,1569$.

9 (a) C. Martínez and K. Muñiz, Angew. Chem. Int. Ed., 2015, 54, 8287. (b) P. Becker, T. Duhamel, J. C. Stein, M. Reiher and K. Muñiz, Angew. Chem. Int. Ed., 2017, 56, 8004.

10 (a) M. D. Kärkäs, ACS Catal., 2017, 7, 4999. (b) T. Xiong and Q. Zhang, Chem. Soc. Rev., 2016, 45, 3069. (c) J.-R. Chen, X.-Q. Hu, L.-Q. Lu and W.-J. Xiao, Chem. Soc. Rev., 2016, 45, 2044. (d) L. Q. Nguyen and R. R. Knowles, ACS Catalysis, 2016, 6, 2894.

11 For the case of catalytic amidyl radicals: H. Zhang and $\mathrm{K}$. Muñiz, ACS Catal., 2017, 7, 4122.

12 For recent reviews on electroorganic synthesis, see: (a) B. A. Frontana-Uribe, R. D. Little, J. G. Ibanez, A. Palma and R. Vasquez-Medrano, Green Chem., 2010, 12, 2099. (b) M. Yan, Y. Kawamata and P. S. Baran, Chem. Rev., 2017, 117, 13230. (c) J.-i. Yoshida, K. Kataoka, R. Horcajada and A. Nagaki, Chem. Rev., 2008, 108, 2265. (d) E. J. Horn, B. R. Rosen and P. S. Baran, ACS Cent. Sci., 2016, 2, 302. (e) Y. Jiang, K. Xu and C. Zeng, Chem. Rev., 2018, 118, 4485. (f) A. Wiebe, T. Gieshoff, S. Möhle, E. Rodrigo, M. Zirbes and S. R. Waldvogel, Angew. Chem. Int. Ed., 2018, 57, 5594. (g) S. Möhle, M. Zirbes, E. Rodrigo, T. Gieshoff, A. Wiebe and S. R. Waldvogel, Angew. Chem. Int. Ed., 2018, 57, 6018. (h) R. Francke and R. D. Little, Chem. Soc. Rev., 2014, 43, 2492. (i) Y.-i. Yoshida, A. Shimizu and R. Hayashi, Chem. Rev., 2018, 118, 4702.

13 For selected recent examples of synthetic organic electrochemistry, see: (a) A. Wiebe, B. Riehl, S. Lips, R. Franke and S. R. Waldvogel, Sci. Adv., 2017, 3, eaao3920/1-7. (b) T. Broese and R. Francke, Org. Lett., 2016, 18, 5896. (c) B. Schille, N. O. Giltzau and R. Francke, Angew. Chem. Int. Ed., 2018, 57, 422. (d) Y. Kawamata, M. Yan, Z. Liu, D.-H. Bao, J. Chen, J. T. Starr and P. S. Baran, J. Am. Chem. Soc., 2017, 139, 7448. (e) R. Hayashi, A. Shimizu and J.-i. Yoshida, J. Am. Chem. Soc., 2016, 138, 8400. (f) H.-B. Zhao, A.-J. Liu, J. Song and H.-C. Xu, Angew. Chem. Int. Ed., 2017, 56, 12732. (g) A. A. FolgueirasAmador, K. Philipps, S. Guilbaud, J. Poelakker and T. Wirth, Angew. Chem. Int. Ed., 2017, 56, 15446.

14 (a) H.-C. Xu and K. D. Moeller, J. Am. Chem. Soc., 2008, 130, 13542. (b) H.-C. Xu and K. D. Moeller, J. Am. Chem. Soc., 2010, 132, 2839. (c) J. M. Campbell, H.-C. Xu and K. D. Moeller, J. Am. Chem. Soc., 2012, 134, 18338. (d) Y. Ashikari, T. Nokami and J.-i. Yoshida, Org. Biomol. Chem., 2013, 11, 3322. (e) S. Liang, C.-C. Zeng, X.-G. Luo, F.-z. Ren, H.-Y. Tian, B.-G. Sun and R. D. Little, Green Chem., 2016, 18, 2222. (f) M. Tokuda, T. Miyamoto, H. Fujita and H. Suginome, Tetrahedron, 1991, 47, 747. (g) S. Karady, E. G. Corley, N. L. Abramson, J. S. Amato and L. M. Weinstock, Tetrahedron, 1991, 47, 757.

15 (a) R. Hayashi, A. Shimizu, Y. Song, Y. Ashikari, T. Nokami and J.-i. Yoshida, Chem. Eur. J., 2017, 23, 61. (b) T. Morofuji, A. Shimizu and J.-i. Yoshida, J. Am. Chem. Soc., 2014, 136, 4496. (c) T. Fuchigami, T. Sato and T. Nonaka, J. Org. Chem., 1986, 51, 366. For $\mathrm{C}\left(\mathrm{sp}^{3}\right)-\mathrm{H}$ amination via anodic Ritter-type reaction, see: (d) O. Hammerich and J. H. P. Utley, in Organic Electrochemistry, $5^{\text {th }}$ Ed., (Eds.: O Hammerich, B. Speiser), CRC Press, Boca Raton, 2016, Pp. 781-783.

16 See Supporting Information for details.
17 Selected references for the use of HFIP in synthetic organic electrochemistry, see: (a) B. Elsler, D. Schollmeyer, K. M. Dyballa, R. Franke and S. R. Waldvogel, Angew. Chem. Int. Ed., 2014, 53, 5210. (b) A. Wiebe, D. Schollmeyer, K. M. Dyballa, R. Franke and S. R. Waldvogel, Angew. Chem. Int. Ed., 2016, 55, 11801. (c) T. Gieshoff, D. Schollmeyer and S. R. Waldvogel, Angew. Chem. Int. Ed., 2016, 55, 9437.

18 Stabilization effects of HFIP on radical cations, see: (a) L. Eberson, M. P. Hartshorn and O. Persson, J. Chem. Soc., Perkin Trans 2, 1995, 1735. (b) L. Eberson, O. Persson and M. P. Hartshorn, Angew. Chem. Int. Ed. Engl., 1995, 34, 2268.

19 While conducting our studies, a report was published, describing such an electrochemical lactone formation. However, under our conditions a higher yield of the phenyl substituted lactone $\mathbf{4 b}$ was obtained, see: S. Zhang, L. Li, H. Wang, Q. Li, W. Liu, K. Xu and C. Zeng, Org. Lett., 2018, 20, 252.

20 F. Francke, D. Cericola, D. Weingarth, R. Kötz and S. R. Waldvogel, Electrochim. Acta, 2012, 62, 372.

21 In line with this observation, a pyridine-containing substrate undergoes sulphonamide oxidation prior to oxidation of the electron-poor arene core. ${ }^{16}$

22 The estimated pKa of a toluene radical-cation in acetonitrile is between -9 and -13 thus making it an extremely strong acid that deprotonates readily even in moderately acidic media: A. M. P. Nicholas and D. R. Arnold, Can. J. Chem., 1982, 60, 2165.

23 (a) D. D. M. Wayner, D. J. McPhee and D. Griller, J. Am. Chem. Soc., 1988, 110, 132. (b) O. Hammerich, in Organic Electrochemistry, $5^{\text {th }}$ Ed., (Eds.: O. Hammerich, B. Speiser), CRC Press, Boca Raton, 2016, Pp. 892-894 and 907-909.

24 T. Shono, Tetrahedron, 1984, 40, 811.

25 (a) T. Shono, Y. Matsumura and K. Tsubata, J. Am. Chem. Soc., 1981, 103, 1172. (b) A. M. Jones and C. E. Banks, Beilstein J. Org. Chem., 2014, 10, 3056. 
Table of contents:

An electrochemical $\mathrm{C}-\mathrm{H}$ amination process enables the sustainable unified access to the heterocyclic classes of pyrrolidines and piperidines.

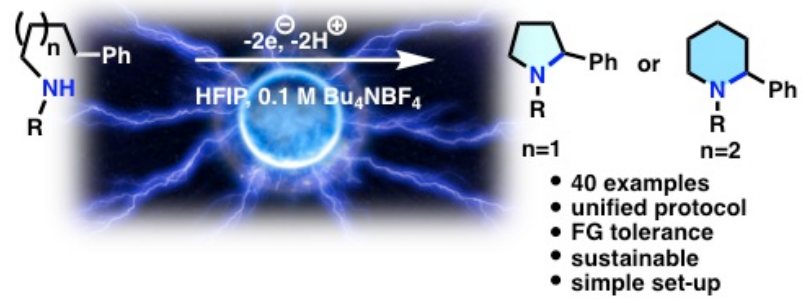

6 | J. Name., 2012, 00, 1-3 